\title{
Tolerance induction to saline stress in papaya seeds treated with potassium nitrate and sildenafil citrate
}

\section{Indução da tolerância ao estresse salino em sementes de mamão tratadas com nitrato de potássio e citrato de sildenafila}

\author{
Rafael Fonsêca Zanotti1 ${ }^{1}$; José Carlos Lopes ${ }^{2 *}$; Ludymila Brandão Motta ${ }^{1}$; \\ Allan Rocha de Freitas ${ }^{3}$; Liana Hilda Golin Mengarda ${ }^{1}$
}

\begin{abstract}
Papaya fruit (Carica papaya) is a species of great commercial agriculture importance. Although has a saline stress sensitivity. Potassium nitrate $\left(\mathrm{KNO}_{3}\right)$ and nitric oxide are substances that inducing saline stress tolerance. The aim of this study was evaluate the effects of sildenafil citrate (SC) and $\mathrm{KNO}_{3}$ on the papaya seeds germination of under saline stress. Papaya seeds of hybrids Calimosa and JS12x Waimanalo were immersed in distilled water or $\mathrm{KNO}_{3}$ solutions and $\mathrm{SC}$ and followed germinated in distilled water or $\mathrm{NaCl}$ solution - $0.3 \mathrm{MPa}$. Seeds of the hybrid JS12x Waimanalo had higher percentages of germination and normal seedlings. The controls of the two hybrids did not show saline stress tolerance during germination. Seeds of the hybrid JS12x Waimanalo, when treated with $\mathrm{KNO}_{3}$ or $\mathrm{SC}$ showed stress tolerance. The growth regulators tested were important in the induction of saline tolerance in papaya seeds.
\end{abstract}

Key words: Carica papaya, $\mathrm{KNO}_{3}$, nitric oxide, salinity

\section{Resumo}

O mamão (Carica papaya) é uma espécie agrícola de grande importância comercial. Porém apresenta sensibilidade ao estresse salino. O nitrato de potássio $\left(\mathrm{KNO}_{3}\right)$ e o oxido nítrico são substancias capazes de induzir tolerância ao estresse salino. O objetivo deste trabalho foi avaliar os efeitos $\mathrm{KNO}_{3}$ e do citrato de sildenafrila (CS) na germinação de sementes de mamão sob estresse salino. Sementes de mamão dos híbridos Calimosa e JS12 x Waimanalo foram tratadas por imersão em água destilada, em soluções $\mathrm{KNO}_{3}$ e de $\mathrm{CS}$ e, em seguida, colocadas para germinar em água destilada ou em solução de $\mathrm{NaCl}-0.3 \mathrm{MPa}$. As sementes do híbrido JS12 x Waimanalo apresentaram maiores porcentagens de germinação e plântulas normais. Os controles dos dois híbridos não apresentaram tolerância ao estresse salino durante a germinação. As sementes do híbrido JS12 x Waimanalo, quando tratadas com $\mathrm{KNO}_{3}$ ou CS apresentaram tolerância ao estresse. Os reguladores de crescimento testados foram importantes na indução à tolerância ao estresse salino em sementes de mamão.

Palavras-chave: Carica papaya, $\mathrm{KNO}_{3}$, óxido nítrico, salinidade

\footnotetext{
${ }^{1}$ Biólogos, Discentes de Doutorado em Produção Vegetal, Programa de Pós-graduação em Produção Vegetal, Centro de Ciências Agrárias, Universidade Federal do Espírito Santo, CCA/UFES, Alegre, ES, Brasil.E-mail: rfzanotti@gmail.com; ludymilamotta@ gmail.com; lianahgm@gmail.com

${ }^{2}$ Eng $^{\circ}$ Agr $^{\circ}$, Prof. Dr. da CCA/UFES, Alegre, ES, Brasil. E-mail: jcufes@bol.com.br

${ }^{3}$ Eng $^{\circ}$ Agr $^{\circ}$, Discente de Doutorado em Produção Vegetal, Programa de Pós-graduação em Produção Vegetal, CCA/UFES, Alegre, ES, Brasil. E-mail: allanrochaf@gmail.com

* Author for correspondence
} 
Brazil is the largest producer of papaya fruits (Carica papaya L.) in the world, with a production of 18 million tons in 2009 and moving 1.34 billion Brazilian Reais (IBRAF, 2012). However, the production and development of papaya trees are compromised in environments that present higher salinity, since papaya is a sensitive species to the concentration of salts in the soil (KOTTENMEIER et al., 1983).

The saline stress changes the physiology of the plants due to the ionic toxicity, osmotic stress and increased reactive oxygen species (ros) (MITTLER, 2002), leading to a gradual peroxidation of the lipids and inactivation of antioxidant enzymes (TANOU; MOLASSIOTIS; DIAMANTIDIS, 2009). The salt stress with $\mathrm{NaCl}$ inhibited the emergence and initial development of papaya seedlings (CAVALCANTE et al., 2010) and these alterations can cause losses in the decrease in fruit productivity.

The nitric oxide (NO) in plants under saline stress modulates the production of the ros and reinforces the activity of the antioxidant enzymes (SINGH et al., 2008). It is considered an important growth regulator, which develops in the plants the tolerance to saline and hydric stress. This is due to the increased activity of antioxidant enzymes such as superoxide dismutase (SOD) and catalase (CAT) (KOPYRA; GWÓZDZ, 2003). One of the ways to release NO in cells is through the sildenafil citrate $(\mathrm{SC})$, the active chemical in Viagra ${ }^{\circledR}$, a medicine used in the treatment of male erection, as a donor of NO (SIEGEL-ITZKOVICH, 1999).

The nitrate is the biggest source of nitrogen for plants. In high doses, it can help to correct nutritional unbalance and promote plant growth even under saline stress (SONG et al., 2006). It is claimed that the effects of the nitrate on the development of plants is the combination of the osmotic effect with the acquisition of water by the plant and the nutritional effect with the protein synthesis (MCINTYRE, 1997).

The aim of this work was to assess the germination of papaya seeds treated with potassium nitrate and sildenafil citrate under saline stress.

The work was performed at the Seed Analysis Laboratory of the Center for Agronomic Sciences (Laboratório de Análises de Sementes do Centro de Ciências Agrárias), UFES, Alegre- ES, Brazil, using papaya seeds (Carica papaya L.) Calimosa and hybrid JS12 x Waimanalo. The seeds were obtained from hermaphrodite fruits collected in maturation stage 5 (mature, with more than 75\% of the external surface in yellow), as per Aroucha et al. (2005). After extracted from the fruits, the seeds were kept under refrigeration $\left(3^{\circ} \mathrm{C}\right)$ for eight months until the beginning of the experiment.

The seeds were initially immersed in distilled water, in solution or $100 \mathrm{~g} \mathrm{~L}^{-1}$ of $\mathrm{KNO}_{3}$ or $500 \mathrm{mg}$ $\mathrm{L}^{-1}$ of sildenafil citrate (SC), for $60 \mathrm{~min}$, followed by rinsing under current water, previously to the germination trial that was conducted in towel paper moisturized with distilled water or solution of $\mathrm{NaCl}$ with potential of $-0.3 \mathrm{MPa}$, equivalent to 2.5 times the mass of the dry paper, to simulated the absence or presence or salt stress.

Rolls were made and kept in a BOD type germinator under isotherm of $20{ }^{\circ} \mathrm{C}$, in the dark, for germination experiment. The treatments were composed by the following combinations: [genotypes (2) $x$ growth regulator (3)] in the absence and presence of saline stress $(\mathrm{NaCl}-0.3 \mathrm{MPa})$.

The germination was daily assessed during 30 days, and the seeds regarded as germinated were the ones presenting a primary root protrusion with length $\geq 2 \mathrm{~mm}$. In addition, it was assessed the number of normal seedlings, seedlings that presented aerial portion with length $\geq 2 \mathrm{~cm}$ and overall length of $\pm 5 \mathrm{~cm}$. Germination percentages were recorded at 14 and 30 days after seeding (BRASIL, 2009). Data obtained from daily counts were used in the calculation of the germination speed index (GSI), as per Maguire (1962).

The design of experiments used was the fully randomized, with four repetitions per treatment. The 
results were submitted to variance analysis and the averages obtained for each treatment were compared through the Tukey test, with 5\% probability level.

There were no differences between the germination of Calimosa seeds in the absence or in the presence of saline stress. The highest percentage of germination in Calimosa seeds occurred when treated with $\mathrm{KNO}_{3}$, suggested as an effective method to promote the germination of such seeds. According to Tokuhisa et al. (2007), the nitrate, in the concentration of $1 \mathrm{~mol} \mathrm{~L}^{-1}$ per $60 \mathrm{~min}$ is one of the best treatments to overcome numbness and accelerate the germination of papaya seeds.

Seeds from the hybrid JS12 x Waimanalo resented the highest percentages of germination when germinated in the absence of saline stress. This occurs because the papaya is very sensitive to the saline and hydric stress (KOTTENMEIER et al., 1983). When seeds were kept under saline stress, there was a lower germination in the absence of $\mathrm{KNO}_{3}$ or sildenafil citrate (Table 1).

Calimosa seeds treated with $\mathrm{KNO}_{3}$ and not submitted to saline stress presented higher percentages of regular seedlings. However, higher percentages of regular seedlings were generated by hybrid seeds of JS12 x Waimanalo, when not exposed to growth regulators and in the absence of saline stress. The seeds of the hybrid JS12 x Waimanalo, when not treated with growth regulator and saline stress, presented a decrease of 55 percentage points regarding the control. However, when treated with $\mathrm{KNO}_{3}$ or $\mathrm{SC}$, they increased 19 percentage points under saline stress, without growth regulators (Table 1).

The highest tolerance of papaya seeds under saline stress may be associated to the increased activity of the antioxidant enzymes or increased seeds respiratory rate (KOPYRA; GWÓZDZ, 2003; ZHENG et al., 2009).
Growth regulators used in the seeds of hybrid JS12 x Waimanalo, kept under saline stress, presented reduced germination regarding the control. The nitrate as inhibitor of the enzyme superoxide dismutase (VIKTOROVA et al., 2010) might have enabled the increase of free radicals, thus reducing the percentage of regular seedlings. Also, since the NO increases the respiratory rate (ZHENG et al., 2009) consequently there is a higher accumulation of ros, which may damage the seeds' cells and cause peroxidation of membrane lipids.

Another factor that influences the reduction of regular seedlings treated with $\mathrm{KNO}_{3}$ is the hydric and/or saline stress, since the concentration of $1 \mathrm{~mol}$ $\mathrm{L}^{-1}$ (hydric potential of $-4.46 \mathrm{MPa}$ ), which was used during $60 \mathrm{~min}$, may have caused damages to the seeds. The germination of papaya seeds is inhibited under salinity levels of 2500 to $3200 \mathrm{mg} \mathrm{L}^{-1}$ of $\mathrm{KNO}_{3}$, with hydric potential of about $-0.22 \mathrm{MPa}$ (KOTTENMEIER et al., 1983).

The highest values of germination speed index (GSI) and germination percentages after 14 days of seeding (firs germination count) were obtained from the seeds of the hybrid JS12 x Waimanalo, but, when those were kept under saline stress, they presented lower GSI and germination values in the first count (Table 1).

Seeds previously treated with $\mathrm{KNO}_{3}$ or $\mathrm{SC}$ presented higher GSI values and first germination count if compared to non-treated seeds and seeds kept under saline stress. $\mathrm{KNO}_{3}$ and $\mathrm{SC}$ are growth regulators that induce the plants to tolerance and development in saline environments, as observed for corn (ESCOBAR et al., 2010) and wheat (ZHENG et al., 2009). 
Table 1. Germination (G), normal seedlings (NS), germination 14 days after sowing (FC) and germination speed index (GIS) of papaya seeds Calimosa and JS12 x Waimanalo treated with potassium nitrate $\left(\mathrm{KNO}_{3}\right)$ and sildenafil citrate $(\mathrm{SC}))$ in the absence and presence of saline stress $(\mathrm{NaCl}-0.3 \mathrm{MPa})$.

\begin{tabular}{llllllllc}
\hline \multirow{2}{*}{ Trat. } & \multicolumn{2}{c}{$\mathrm{G}(\%)$} & \multicolumn{2}{c}{$\mathrm{NS}(\%)$} & \multicolumn{2}{c}{$\mathrm{FC}(\%)$} & \multicolumn{2}{c}{ GSI } \\
\cline { 2 - 9 } & $-\mathrm{NaCl}$ & $+\mathrm{NaCl}$ & $-/ \mathrm{NaCl}$ & $+\mathrm{NaCl}$ & $-\mathrm{NaCl}$ & $+\mathrm{NaCl}$ & $-\mathrm{NaCl}$ & $+\mathrm{NaCl}$ \\
\hline T1 & $60 \mathrm{bA} *$ & $58 \mathrm{bcA}$ & $0 \mathrm{dA}$ & $0 \mathrm{cA}$ & $0 \mathrm{bA}$ & $0 \mathrm{bA}$ & $0.54 \mathrm{cA}$ & $0.51 \mathrm{bA}$ \\
T2 & $81 \mathrm{aA}$ & $74 \mathrm{abA}$ & $13 \mathrm{cdA}$ & $0 \mathrm{cB}$ & $9 \mathrm{bA}$ & $0 \mathrm{bA}$ & $0.85 \mathrm{bA}$ & $0.66 \mathrm{bB}$ \\
$\mathrm{T} 3$ & $51 \mathrm{bA}$ & $51 \mathrm{cA}$ & $0 \mathrm{dA}$ & $0 \mathrm{cA}$ & $0 \mathrm{bA}$ & $0 \mathrm{bA}$ & $0.46 \mathrm{cA}$ & $0.45 \mathrm{bA}$ \\
$\mathrm{T} 4$ & $88 \mathrm{aA}$ & $51 \mathrm{cB}$ & $82 \mathrm{aA}$ & $27 \mathrm{bB}$ & $76 \mathrm{aA}$ & $10 \mathrm{bB}$ & $1.98 \mathrm{aA}$ & $0.65 \mathrm{bB}$ \\
T5 & $88 \mathrm{aA}$ & $86 \mathrm{aA}$ & $19 \mathrm{cB}$ & $47 \mathrm{aA}$ & $76 \mathrm{aA}$ & $34 \mathrm{aB}$ & $1.94 \mathrm{aA}$ & $1.37 \mathrm{aB}$ \\
T6 & $88 \mathrm{aA}$ & $79 \mathrm{aA}$ & $67 \mathrm{bA}$ & $45 \mathrm{aB}$ & $72 \mathrm{aA}$ & $27 \mathrm{aB}$ & $1.88 \mathrm{aA}$ & $1.15 \mathrm{aB}$ \\
\hline
\end{tabular}

*Means within columns followed by different lowercase letters and within line uppercase differ at Tukey test $(\mathrm{P} \leq 0.05) . n=4 \pm \mathrm{SE}$. T1: Calimosa $+\mathrm{H}_{2} \mathrm{O}$; T2: Calimosa $+\mathrm{KNO}_{3}$; T3: Calimosa $+\mathrm{SC}$; : JS12 x Waimanalo $+\mathrm{H}_{2} \mathrm{O}$, T5: JS12 x Waimanalo + KN0 ${ }_{3}$, T6: JS12 x Waimanalo + SC.

Source: Elaboration of the authors.

The papaya seeds are sensitive to saline stress during the germination, although JS12 $\mathrm{x}$ Waimanalo genotype can be reversed the deleterious effects with the use of sildenafil citrate or potassium nitrate.

Acknowledgements to Caliman Agrícola S/A to send the fruits and CAPES/REUNI and CNPq for the scholarship granted to the first author and foment to the second author.

\section{References}

AROUCHA, E. M. M.; SILVA, R. F.; OLIVEIRA, J. G.; VIANA, A. P.; GONZAGA, M. P. Época de colheita e período de repouso dos frutos de mamão (Carica papaya L.) cv. Golden na qualidade fisiológica das sementes. Ciência Rural, Santa Maria, v. 35, n. 3, p. 537-543, 2005. Disponível em: <http://www.scielo.br/pdf/cr/v35n3/ a08v35n3.pdf>. Acesso em: 20 may 2012.

BRASIL. Ministério da Agricultura, Pecuária e Abastecimento.Secretaria de Defesa Agropecuária. Regras para análise de sementes. Brasília, DF: Mapa/ ACS, 2009. 395 p. Disponível em: <http://www.bs.cca. ufsc.br/publicacoes/regras\%20analise $\% 20$ sementes. pdf $>$. Acesso em: 20 maio 2012.

CAVALCANTE, L. F.; CORDEIRO, J. C.; NASCIMENTO, J. A. M.; CAVALCANTE, I. H. L.; DIAS, T. J. Fontes e níveis da salinidade da água na formação de mudas de mamoeiro cv. sunrise solo. Semina: Ciências Agrárias, Londrina, v. 31, p. 1281-
1290, 2010. Disponível em: <http://www.uel.br/revistas/ uel/index.php/semagrarias/article/viewArticle/3245>. Acesso em: 10 jun. 2012.

ESCOBAR, H.; BUSTOS, R.; FERNÁNDEZ, F.; CÁRCAMO, H.; SILVA, H.; FRANK, N.; CARDEMIL, L. Mitigation effect of salicylic acid and nitrate on water relations and osmotic adjustment in maize, cv. Lluteño exposed to salinity. Ciencia e Investigación Agraria, Santiago de Chile, v. 37, n. 3, p. 71-81, 2010. Available from: <http://www.scielo.cl/pdf/ciagr/v37n3/art06.pdf>. Accessed at: 01 jun. 2012.

INSTITUTO BRASILEIRO DE FRUTAS I- BRAF. Produção brasileira de frutas. 2012. Disponível em: $<$ http://www.ibraf.org.br>. Acesso em: 01 jun. 2012.

KOPYRA, M.; GWÓŹDŹ, E. A. Nitric oxide stimulates seed germination and counteracts the inhibitory effect of heavy metals and salinity on root growth of Lupinus luteus. Plant Physiology and Biochemistry, Bari, v. 41, n. 11-12, p. 1011-1017, 2003. Available at: $<$ http://www.ac.els-cdn.com/S0981942803001 75X/1-s2.0-S098194280300175X-main.pdf?_tid $=7 \mathrm{c} 10 \mathrm{bcd} 6 \mathrm{f} 95 \mathrm{e} 8 \mathrm{~d} 37705 \mathrm{dabdda} 84 \mathrm{bee} 9 \mathrm{a} \& \mathrm{acdnat}=$ 3070804_1394718a98064ad5623d5ca0725ef4c1>. Accessed at: 01 jun. 2012.

KOTTENMEIER, W.; CHANG, J.; SIEGEL, S. M.; SIEGEL, B. Z. Stimulation of growth in papaya and other plants by dilute salt solutions. Water, Air, Soil and Pollution, Dordrecht, v. 20, n. 4, p. 447-450, 1983.

MAGUIRE, J. D. Speed of germination - AID seedling emergence and vigor. Crop Science, Madison, v. 2, p. 176-177, 1962. 
MCINTYRE, G. I. The role of nitrate in the osmotic and nutritional control of plant development. Australian Journal of Plant Physiology, Sydney, v. 24, n. 2, p. 103-118, 1997. Available at: <http://www.publish.csiro. au/?act=view_file\&file_id=PP96064.pdf $>$. Accessed at: 01 jun. 2012.

MITTLER, R. Oxidative stress, antioxidants and stress tolerance. Trends in plant science, Oxford, v. 7, n. 9, p. 405-410, 2002. Available at: $<$ http://www.sciencedirect. com/science/article/pii/S1360138502023129>. Accessed at: 01 jun. 2012.

SIEGEL-ITZKOVICH, J. Viagra makes flowers stand up straight. BMJ: British Medical Journal, London, v. 319, n. 7205 , p. 274, 1999. Available at: http://www.ncbi.nlm. nih.gov/pmc/articles/PMC1126921/>. Accessed at: 01 jun. 2012 .

SINGH, H. P.; BATISH, D. R.; KAUR, G.; ARORA, K.; KOHLI, R. K. Nitric oxide (as sodium nitroprusside) supplementation ameliorates Cd toxicity in hydroponically grown wheat roots. Environmental and Experimental Botany, Elmsford, v. 63, n. 1-3, p. 158-167, 2008. Available at: <http:// www.ac.els-cdn. com/S0098847207002596/1-s2.0-S0098847207002596main.pdf? tid=a22b648938923 e709f55b6a6ae7c20fb\& acdnat $=1343074733 \_21 \mathrm{ccfbe} 1 \mathrm{f} 09 \mathrm{dbd} 517 \mathrm{~d} 8 \mathrm{~d} 7 \mathrm{fbc} 8 \mathrm{a} 4 \mathrm{ea}$ 6e1>. Accessed at: 01 jun. 2012.

SONG, J.; DING, X.; FENG, G.; ZHANG, F. Nutritional and osmotic roles of nitrate in a euhalophyte and a xerophyte in saline conditions. New Phytologist, Cambridge, v. 171 , n. 2, p. 357-366, 2006. Available at: $<$ http://onlinelibrary.wiley.com/doi/10.1111/j.14698137.2006.01748.x/full>. Accessed at: 01 jun. 2012.
TANOU, G.; MOLASSIOTIS, A.; DIAMANTIDIS, G. Induction of reactive oxygen species and necrotic death-like destruction in strawberry leaves by salinity. Environmental and Experimental Botany, Elmsford, v. 65 , n. $2-3$, p. $270-281,2009$. Available at: $<$ http:// www.ac.els-cdn.com/S009884720800107X/1-s2.0S009884720800107X-main.pdf?_tid=0416a5f595 $1 \mathrm{dc} 45367 \mathrm{~d} 5 \mathrm{f} 9868 \mathrm{~b} 615310 \&$ acdnat $=1343074904$ $339 \mathrm{c} 03 \mathrm{f} 3 \mathrm{~d} 22359500 \mathrm{~b} 4 \mathrm{f} 3 \mathrm{fc} 8 \mathrm{ac} 4 \mathrm{f} 3 \mathrm{~b} 23>$. Accessed at: 01 jun. 2012.

TOKUHISA, D.; DIAS, D. C. F. S.; ALVARENGA, E. M.; DIAS, L. A. S.; MARIN, S. L. D. Tratamentos para superação da dormência em sementes de mamão. Revista Brasileira de Sementes, Brasília, v. 2, n. 1, p. 131-139, 2007. Disponível em: <http://www.scielo.br/pdf/rbs/ v29n1/18.pdf $>$. Acesso em 10 jun. 2012.

VIKTOROVA, L. V.; MAKSYUTOVA, N. N.; TRIFONOVA, T. V.; ANDRIANOV, V. V. Production of hydrogen peroxide and nitric oxide following introduction of nitrate and nitrite into wheat leaf apoplast. Biochemistry, Moscow, v. 75, n. 1, p. 95-100, 2010.

ZHENG, C. F.; JIANG, D.; LIU, F. L.; DAI, T. B.; LIU, W. C.; JING, Q.; CAO, W. X. Exogenous nitric oxide improves seed germination in wheat against mitochondrial oxidative damage induced by high salinity. Environmental and Experimental Botany, Elmsford, v. 67, n. 1, p. 222-227, 2009. Available at: $<$ http: $\quad$ www.//ac.els-cdn.com/S0098847209000896/1s2.0-S0098847209000896-main.pdf? tid=8e3646c1371 $8338 \mathrm{~d} 63 \mathrm{e} 63 \mathrm{fd} 28274265 \mathrm{~d} \&$ acdnat $\quad=1343075098$ d76588bc233a4cee8e14a0d0f12effbf $>$. Accessed at: $0 \overline{8}$ jun. 2012. 
